\title{
Viabilitas dan Aktivitas Antibakteri Bifidobacterium bifidum dalam Susu Bifidus dengan Suplementasi Ekstrak Cengkeh (Syzygium aromaticum)
}

Viability and Antibacterial Activity of Bifidobacterium bifidum in Bifidus Milk Supplemented with Clove Extract (Syzygium aromaticum)

\section{Nosa Septiana Anindita ${ }^{1 *}$, Muslih Anwar ${ }^{2}$}

${ }^{1}$ Program Studi Bioteknologi, Universitas 'Aisyiyah Yogyakarta

Jl. Ringroad Barat No. 63, Mlangi Nogotirto, Kec. Gamping, Kab. Sleman, Yogyakarta 55592, Indonesia Balai Penelitian Teknologi Bahan Alam (BPTBA), Lembaga Ilmu Pengetahuan Indonesia (LIPI) Jl. Jogja - Wonosari, km. 31, 5, Kec. Playen, 174 Wonosari, Gading, Kabupaten Gunung Kidul, Yogyakarta 55861, Indonesia

*Penulis korepondensi: Nosa Septiana Anindita, Email: nosa.nindita@unisayogya.ac.id

Tanggal submisi: 13 November 2018; Tanggal revisi: 26 April 2020; Tanggal penerimaan: 10 Juli 2020

\begin{abstract}
ABSTRAK
Pengembangan produk olahan susu kambing terfermentasi dan diperkaya dengan probiotik Bifidobacterium bifidum merupakan salah satu produk pangan fungsional (Functional Food) yang selanjutnya disebut sebagai Susu Bifidus. Susu bifidus sebagai salah satu produk fermentasi susu dapat dikonsumsi oleh masyarakat yang mengalami kesulitan mencerna laktosa (lactose intolerance). Daya terima konsumen terhadap susu kambing masih tergolong rendah dibandingkan dengan susu sapi, sehingga hal tersebut juga perlu diantisipasi. Penambahan ekstrak cengkeh (Syzygium aromaticum) pada susu Bifidus dapat digunakan sebagai alternatif senyawa aromatik alami, untuk menghilangkan aroma goaty pada susu kambing yang kurang begitu disukai oleh konsumen. Penelitian ini bertujuan untuk mengetahui pengaruh suplementasi ekstrak cengkeh terhadap viabilitas (daya hidup) dan aktivitas antibakteri Bifidobacterium bifidum serta kualitas kimia susu Bifidus. Parameter yang diamati pada penelitian adalah total Bifidobacterium bifidum, total bakteri dan luas zona bening susu Bifidus. Suplementasi ekstrak cengkeh sebesar $2 \%$ sebagai bahan suplementasi pada Bifidus milk dapat meningkatkan viabilitas probiotik Bifidobacterium bifidum. Ekstrak cengkeh dalam produk Bifidus milk berperan sebagai agen preservatif, didukung dengan adanya aktivitas antibakteri terhadap Staphylococcus aureus dan Salmonella typhimurium dan penurunan total bakteri pada Bifidus milk.
\end{abstract}

Kata kunci: Bifidobacterium bifidum; susu bifidus; ekstrak cengkeh; Syzygium aromaticum 


\begin{abstract}
Diversification of fermented goat milk processed products and enriched with probiotics Bifidobacterium bifidum is one of the functional food products (Functional Food) which is hereinafter referred to as Milk Bifidus. Milk bifidus as one of the fermented milk products can be consumed by people who have difficulty digesting lactose (lactose intolerance). Consumer acceptance of goat milk is still relatively low compared to cow's milk, so it also needs to be anticipated. The addition of clove extract (Syzygium aromaticum) to Bifidus milk can be used as an alternative to natural aromatic compounds, to eliminate goaty scent in goat milk which is less preferred by consumers. This study purpose was to determine the effect of clove extract supplementation on the viability and antibacterial activity of Bifidobacterium bifidum and the chemical quality of Bifidus milk. The parameters observed in the study were total Bifidobacterium bifidum, total bacteria and the area of clear zone of Bifidus milk. Supplementation of $2 \%$ clove extract as a supplement for Bifidus milk can increase the viability of probiotics in Bifidobacterium bifidum. Clove extract in Bifidus milk products acts as a preservative agent, supported by the presence of antibacterial activity against Staphylococcus aureus and Salmonella typhimurium and a total decrease in bacteria in Bifidus milk.
\end{abstract}

Keywords: Bifidobacterium bifidum; bifidus milk; clove extract; Syzygium aromaticum

\section{PENDAHULUAN}

Kesadaran akan pola hidup sehat saat ini cenderung mengalami peningkatan, seiring dengan meningkatnya tingkat pendidikan, status sosial ekonomi dan perubahan gaya hidup masyarakat. Hal ini menyebabkan permintaan konsumen atas pangan fungsional menjadi semakin meningkat. Produk pangan fungsional banyak berasal dari protein hewani yaitu susu. Pemanfaatan protein hewani, salah satunya adalah susu kambing. Taofik dan Depison (2008) menyatakan bahwa susu kambing Peranakan Ettawa (PE) terbukti memiliki khasiat untuk meningkatkan kesehatan tubuh. Hal ini juga didukung oleh penelitian yang disampaikan oleh Haenlein pada tahun 2006 bahwa golongan asam lemak tak jenuh tunggal/Mono Unsaturated Fatty Acid (MUFA), asam lemak tak jenuh jamak/Poly Unsaturated Fatty Acid (PUFA) dan trigliserida rantai sedang/Medium Chain Triglycerides (MCT) merupakan komponen nutrisi yang banyak ditemui dalam susu kambing. Ditambahkan pula manfaat susu kambing oleh Banerjee (2008) yang menyatakan bahwa ukuran globula lemak yang sangat kecil, susu kambing memberikan manfaat dalam pencegahan lactose intolerance. Selain itu, Park (2009) juga menyampaikan susu kambing dapat berperan sebagai antimikroba, antihipertensi dan antioksidatif karena keberadaan komponen bioaktif peptida di dalamnya.

Penganekaragaman produk susu kambing fermentasi dapat juga diperkaya dengan adanya suplementasi probiotik. Bakteri yang berpotensi sebagai probiotik dapat digunakan pada proses fermentasi susu. Menurut WHO, probiotik dapat berperan dalam menyeimbangkan mikroflora saluran cerna dengan jumlah bakteri hidup $10^{6}$ sampai $10^{8} \mathrm{CFU} / \mathrm{mL}$. Menurut Widodo (2003), probiotik mempunyai aspek kesehatan yaitu penurunan kasus lactose intolerance, penurunan kadar serum kolesterol, penurunan resiko kanker, penanganan dan pengendalian diare, stimulasi sistem imunitas tubuh dan produksi bakteriosin serta penghambatan patogen.

Andriani (2010) menyampaikan bahwa olahan protein hewani asal susu akibat adanya aktivitas mikrobia sehingga menghasilkan produk dengan organoleptik yang diinginkan serta dapat dimanfaatkan dalam pencegahan lactose intolerance didefinisikan sebagai susu fermentasi. Yakult, yoghurt dan kefir merupakan produk susu fermentasi yang banyak dijumpai di pasaran dan dikonsumsi masyarakat. Perbedaan produk susu fermentasi tersebut terletak pada jenis mikrobia yang memfermentasi dan umumnya adalah kelompok bakteri asam laktat (BAL). Perkembangan saat ini, L. acidophillus dan Bifidobacterium merupakan bakteri probiotik yang banyak disuplementasikan dalam produk susu fermentasi. Hal ini didukung oleh pendapat Irianto (2003) dengan adanya penambahan bakteri probiotik diharapkan dapat memberikan aktivitas fungsional bagi kesehatan.

Salah satu produk susu fermentasi adalah Susu Bifidus (Bifidus Milk) yang kaya akan kandungan bakteri probiotik Bifidobacterium sp. Spesies Bifidobacterium yang banyak dimanfaatkan dalam pembuatan produk ini adalah Bifidobacterium bifidum. Saat ini, di Indonesia produk Susu bifidus ini belum banyak dikenal dan dikembangkan, sehingga berpotensi untuk memberikan kontribusi diversifikasi produk susu fermentasi. Penelitian terkait susu fermentasi telah Gustaw dkk. (2011) laporkan yaitu mengembangkan produk bio-yogurt dengan probiotik L. acidophilus dan Bifidobacterium sp. Untuk meningkatkan viabilitas probiotik selama penyimpanan, produk ditambahkan prebiotik FOS dan inulin. Prebiotik ditambahkan ke dalam produk dalam konsentrasi 1, 2, dan 3\%. Produk 
bio-yogurt dapat disimpan pada suhu $4^{\circ} \mathrm{C}$ selama tiga minggu. Penambahan Fruktooligosakarida (FOS) dan inulin, yang merupakan kelompok serat pangan dapat memberikan efek menguntungkan bagi bakteri probiotik dalam produk fermentasi tersebut. Serat pangan tersebut mampu menstimulasi dan meningkatkan viabilitas atau daya hidup bakteri probiotik apabila dibandingkan dengan produk tanpa penambahan serat pangan tersebut. Viabilitas $S$. thermophilus dengan penambahan 1; 2 dan 3\% FOS berturut-turut adalah 9; 7,8, dan $7.7 \log \mathrm{CFU} / \mathrm{g}$. Viabilitas probiotik bertahan selama 14 hari kemudian menurun, namun tidak sampai mencapai $10^{6} \mathrm{CFU} / \mathrm{g}$.

Pengembangan produk susu kambing sebagai salah satu produk pangan fungsional (Functional Food) atau pangan kesehatan (Nutraceutical Food) adalah susu kambing fermentasi dengan suplementasi bahan alami sebagai agensia aromatik. Hanya saja terkadang konsumen kurang begitu dapat menikmati karena aroma susu kambing yang khas, sehingga perlu diberikan suplementasi bahan aromatik alami seperti cengkeh (Syzygium aromaticum). Cengkeh dapat dimanfaatkan untuk menghilangkan aroma goaty pada susu kambing yang kurang begitu disukai oleh konsumen. Daya terima konsumen dan lamanya masa simpan produk susu kambing fermentasi diharapkan dapat meningkat karena adanya flavour cengkeh yang kuat dan kandungan antioksidan tinggi. Selain itu, flavour cengkeh yang kuat juga dapat menyamarkan aroma prengus/goaty dari susu kambing dan produk olahannya.

Berbagai macam bahan preservatif alami ditambahkan pada olahan pangan. Beberapa peneliti telah melaporkan terkait pemanfaatan bahan preservatif alami pada kualitas olahan pangan. Penelitian yang dilakukan Ambarwati pada tahun 2004 melaporkan adanya kualitas dan lama simpan terhadap total bakteri dan daya terima susu pasteurisasi karena adanya penambahan madu. Hasil pengujian total bakteri terhadap lama simpan menunjukkan nilai tertinggi diperoleh $1,2 \times 10^{3}$ koloni/ $\mathrm{mL}$ atau 3,68 ( $\log \mathrm{CFU} / \mathrm{mL})$ dengan lama simpan 96 jam. Sedangkan total bakteri terendah yaitu $0,8 \times 10^{3}$ koloni/ $\mathrm{mL}$ atau 2,90 (log CFU/mL) pada lama simpan 144 jam.

Penelitian yang dilakukan oleh Miksusanti dkk. (2011) melaporkan terkait penggunaan secang (Caesalpinia sappan L.) sebagai antibakteri. Penelitian ini melaporkan bahwa kadar fenol 590,428 mg/g yang terkandung dalam secang dapat menghambat aktivitas Bacillus cereus. Penelitian Kumala dkk. (2009) dan Kumala dkk. (2013) juga melaporkan bahwa adnya tannin dan asam galat yang terdapat pada rebusan kayu secang mampu menghambat aktivitas bakteri Salmonella thypii dan Escherichia coli secara in vivo. Penelitian pemanfaatan bahan alam dalam olahan pangan, juga dilakukan oleh Maitimu dkk. (2013) bahwa mutu susu pasteurisasi meliputi mikrobiologis, kimia, fisik maupun organoleptik serta profil elektoforesis protein susu pasteurisasi dapat dipertahankan melalui pemanfaatan ekstrak daun Aileru (7,5 dan 10\%) dengan lama penyimpanan 5 jam.

Ekstrak cengkeh aman dan berpotensi sebagai bahan preservatif dan aromatik alami bagi olahan susu (Hakim, 2015). Bagi penderita lactose intolerance, laktosa pada susu kambing yang tinggi menjadi suatu problem tersendiri. Penambahan Bifidobacterium bifidum dharapkan mampu menurunkan nilai laktosa melalui proses fermentasi. Adanya perubahan tersebut, kemungkinan besar akan menyebabkan terjadinya peningkatan jumlah bakteri probiotik, terjadi penurunan jumlah dan adanya aktivitas antibakteri terhadap patogen oleh bakteri probiotik. Berdasarkan latar belakang diatas, maka penelitian terkait viabilitas dan aktivitas antibakteri probiotik Bifidobacterium bifidum dalam susu Bifidus dengan penambahan cengkeh (Syzygium aromaticum) perlu dilakukan. Dari hasil penelitian ini, akan diperoleh produk pangan fungsional yang diperkaya dengan probiotik dengan memanfaatkan bahan alami yaitu cengkeh sebagai preservatif dan aromatik alami.

\section{METODE PENELITIAN}

Penelitian ini dilakukan secara eksperimental dengan menggunakan analisis variansi pola faktorial 2 perlakuan dan 2 waktu dengan 4 kali ulangan. Perlakukan yang ditetapkan yakni: kontrol/tanpa suplementasi ekstrak cengkeh (BM0) dan suplementasi ekstrak cengkeh 2\% (BM2). Data hasil pengamatan dianalisis statistik dengan ANOVA dan untuk mengetahui tingkat perbedaan setiap perlakuan dilanjutkan uji Duncan's New Multiple Range Test pada taraf 5\%. Parameter yang diamati adalah viabilitas probiotik, total bakteri dan aktivitas antibakteri.

\section{Bahan}

Bahan utama yang digunakan dalam penelitian ini adalah susu kambing segar yang diperoleh dari Peternak Kambing Peranakan Ettawa di daerah Turi, cengkeh yang diperoleh dari Samigaluh, Kulon Progo, probiotik (Bifidobacterium bifidum) dan bakteri patogen Staphylococcus aureus dan Salmonella typhimurium yang diperoleh dari Laboratorium Mikrobiologi Pusat Studi Pangan dan Gizi, PAU, UGM. Bahan kimia yang digunakan adalah alkohol 30\%, alkohol 70\%, Nutrient Agar (NA), MRS (Merck), PCA (Merck), aquadest, ethanol $95 \%$. 
Alat

Beberapa peralatan laboratorium yang digunakan diantaranya timbangan analitik, alat-alatgelas laboratorium (Pyrex, Jerman), laminar air flow (MASCOTTE Model LHS/ $L H M / L H L$, Indonesia), spektrofotometer (Thermoscientific Genesys 20 Visible Thermo Scientific, USA), shaker, inkubator (Memmert, Jerman), pH meter, autoklaf, petridis, test tube, sentrifus (Beckmann, Ecco-alpha-1, Amerika Serikat), Vortex (Thermolyne, Amerika Serikat), tabung spektro, drigalski, jarum ose, colony counter, mikropipet, yellow tip, blue tip, penangas, dan Bunsen.

\section{Pembuatan Sediaan Ekstrak Cengkeh}

Cengkeh dihaluskan dengan menggunakan blender hingga diperoleh cengkeh dalam bentuk bubuk. Sebanyak $2 \%(b / v)$ cengkeh bubuk dilarutkan dalam aquadest, yang selanjutnya dilakukan proses perebusan selama 60 menit dengan menggunakan api kecil. Penggunaan api kecil saat perebusan ini bertujuan agar kadar tanin yang diperoleh tinggi (Nurhidayati dan Sulistiowati, 2013). Selama 60 menit, perebusan dipertahankan pada suhu $95-100{ }^{\circ} \mathrm{C}$. Setelah cukup dingin $\left(37^{\circ} \mathrm{C}\right)$, air rebusan cengkeh tersebut disaring dan filtrat digunakan untuk perlakuan. Pembuatan sediaan ekstrak cengkeh ini mengacu pada Winarti dan Sembiring (1998) dengan modifikasi.

\section{Pembuatan Kultur Kerja Bifidobacterium bifidum}

Pembuatan kultur kerja dilakukan pada media MRS Broth sebanyak $5 \mathrm{~mL}$ dengan mengambil dari hasil inokulasi pada agar miring dan diinkubasi pada suhu 37 ${ }^{\circ} \mathrm{C}$ selama 24 jam. Selanjutnya dari hasil peremajaan tersebut, diambil sebanyak $1 \mathrm{~mL}$ dan diinokulasikan pada $9 \mathrm{~mL}$ MRS Broth, untuk selanjutnya diinkubasi pada suhu $37{ }^{\circ} \mathrm{C}$ selama 24 jam. Hasil pembiakan ini selanjutnta disebut dengan F1.

\section{Pembuatan Starter Bifidobacterium bifídum}

Starter dalam susu fermentasi dibuat dengan meremajakan hasil biakan F1. Sebanyak $1 \mathrm{~mL}$ kultur diambil dari $\mathrm{F} 1$ dan diinokulasikan kedalam $9 \mathrm{~mL}$ MRS Broth inkubasi selama 24 jam pada suhu $37^{\circ} \mathrm{C}$. Hasil peremajaan ini selanjutnya disebut sebagai F2. Sebanyak $10 \%$ kultur biakan F2 diinokulasikan ke dalam $100 \mathrm{~mL}$ susu Ultra High Temperature (UHT) dan diinkubasi pada suhu $37{ }^{\circ} \mathrm{C}$ selama 6 jam hingga diperoleh pH 5,2- 5,3 dengan kepadatan starter $10^{6}-10^{7} \mathrm{CFU} / \mathrm{mL}$. Hasil biakan ini selanjutnya disebut sebagai F3.

\section{Pembuatan Susu Bifidus (Bifidus Milk)}

Susu Bifidus (Bifidus Milk) merupakan susu fermentasi dengan menggunakan Bifidobacterium sp.
Bifidus Milk dibuat dengan bahan dasar susu kambing, dengan substitusi ekstrak cengkeh dengan kadar 0 dan $2 \%$ (v/v). Susu kambing segar ditambahkan dengan sediaan ekstrak cengkeh sesuai perlakuan (modifikasi Winarti dan Sembiring (1998) yaitu Bifidus Milk 0\% (BM0) dan Bifidus Milk 2\% (BM2). Campuran tersebut dipasteurisasi pada suhu $85^{\circ} \mathrm{C}$ selama 30 menit diikuti pendinginan sampai suhu $40^{\circ} \mathrm{C}$. Sehingga antara susu kambing segar dan ekstrak cengkeh ditambahkan sebelum pasteurisasi dan ikut dipasteurisasi. Selanjutnya fermentasi dengan probiotik diawali dengan inokulasi starter yang telah dipersiapkan sebanyak $10 \% \mathrm{v} / \mathrm{v}$ dengan densitas $10^{6}-10^{7}$ $\mathrm{CFU} / \mathrm{mL}$. Setelah itu diinkubasi pada suhu $37^{\circ} \mathrm{C}$ selama 9 jam hingga total bakteri $10^{7}-10^{8} \mathrm{CFU} / \mathrm{mL}$ dengan $\mathrm{pH}$ 5,25,3 . Susu fermentasi disimpan dalam refrigerator dengan suhu $5{ }^{\circ} \mathrm{C}$ (Lankaputhra dan Shah, 1997).

Selama proses pembuatan Bifidus milk, oksigen dapat dengan mudah masuk dan terlarut dalam susu. Untuk mengatasinya, oksigen dapat diminimalisir selama proses pembuatan khususnya dengan menambahkan senyawa pereduksi oksigen pada medium seperti L-cystein $\mathrm{HCl}$ $0,05 \%$. Penelitian yang dilakukan oleh Laroia dan Martin (1991) menunjukkan cystein merupakan asam amino yang mengandung sulfur sebagai suplai nitrogen untuk pertumbuhan dan potensial reduksi yang memberikan kondisi anaerobik bagi pertumbuhan Bifidobacteria. Pada proses pembuatan Bifidus milk dengan Bifidobacterium bifidum sebagai probiotik dilakukan penambahan L-cystein $\mathrm{HCl}$ 0,05\% (w/v) sebagai senyawa pereduksi oksigen sesuai dengan pendapat Dave dan Shah (1997). Penghitungan viabilitas probiotik ini menggunakan media MRS Agar dengan penambahan bile salt(B-MRS) sebanyak $0,15 \%$. Bile salt merupakan salah satu hambatan bagi BAL yang bukan merupakan galur probiotik ketika sampai pada saluran pencernaan, sehingga penghitungan dengan penambahan bile salt yang terhitung merupakan bakteri probiotik.

\section{Uji Viabilitas Probiotik}

Perhitungan total bakteri probiotik menggunakan media MRS agar yang ditambah dengan bile salt 0,15\% (w/v) (Vinderola dan Reinheimer, 1999). Pengujian viabilitas probiotik menggunakan metode Total Plate Count (TPC). Sebanyak $1 \mathrm{~mL}$ sampel dimasukkan ke dalam $9 \mathrm{~mL}$ akuades steril sebagai pengenceran $10^{-1}$ dan seterusnya hingga diperoleh pengenceran $10^{-7}$. Sebanyak $0,1 \mathrm{~mL}$ dari pengencern yang dikehendaki selanjutnya diinokulasi dalam cawan petri berisi MRS agar dan diratakan dengan drigalski steril. Cawan petri tersebut diinkubasi dengan posisi terbalik pada suhu $37^{\circ} \mathrm{C}$, 24 jam. Perhitungan bakteri dilakukan dengan menghitung jumlah koloni 25-250 koloni dengan menggunakan colony counter (Wahyu dkk., 2012). 


\section{Pengujian Aktivitas Antibakteri Terhadap Patogen dengan Metode Difusi Sumur Agar}

Deteksi antibakteri terhadap patogen dilakukan menurut metode yang dikemukakan oleh Jacobsen dkk. (1999). Pada permukaan cawan dituang sekitar $15 \mathrm{~mL}$ larutan 1,8\% agar. Setelah memadat, dibuat sumuran dengan meletakkan lempeng berdiameter $1 \mathrm{~cm}$ dan kemudian di sekeliling lempeng dituang 12 $\mathrm{mL}$ MRS agar $1,2 \%$ yang telah ditambahkan $5 \%$ kultur patogen yaitu Staphylococcus aureus dan Salmonella typhimurium yang diperoleh dari Pusat Studi Pangan dan Gizi, UGM. Setelah memadat, pada sumuran kemudian ditambahkan $20 \mu$ sampel Bifidus Milk (BM0 dan BM2) dan diinkubasi suhu $37^{\circ} \mathrm{C}, 48$ jam. Zona bening yang terbentuk setelah 48 jam inkubasi diukur dengan menggunakan jangka sorong. Pengukuran zona bening dilakukan dengan cara mengukur diameter zona yang terbentuk baik vertikal maupun horizontal yang dinyatakan dalam satuan $\mathrm{mm}$. Zona bening dengan ukuran lebih dari $2 \mathrm{~mm}$ pada sekeliling sumuran diindikasikan sebagai penghambatan positif.

\section{Pengujian Total Bakteri}

Total bakteri dihitung dengan metode TPC menggunakan media Plate Count Agar (PCA). Prinsip pengujian ini adalah Bifidus milk baik BM0 dan BM2 dihomogenkan dan dilakukan beberapa kali pengenceran dengan menuang $1 \mathrm{~mL}$ sampel, setelah itu inkubasi suhu $37^{\circ} \mathrm{C}$, 24 sampai 48 jam, maka didapat total bakteri. Total bakteri diperoleh dengan menghitung cawan petri yang berisi 30 sampai 300 koloni (Waluyo, 2008).

\section{HASIL DAN PEMBAHASAN}

\section{Viabilitas Bifidobacterium bifidum dalam Bifidus Milk}

Penghitungan total probiotik dilakukan untuk mengetahui jumlah probiotik hidup (viable) dalam Bifidus milk. Total Bifidobacterium bifidum sebagai probiotik pada Bifidus milk ekstrak cengkeh $2 \%$ (BM2) dan tanpa ekstrak cengkeh (BM0) sebagai kontrol (Tabel 1).

Berdasarkan pengujian statistik, suplementasi ekstrak cengkeh sebanyak $2 \%$ dan waktu fermentasi (sebelum dan sesudah fermentasi) mempengaruhi total probiotik dalam Bifidus milk secara nyata $(p<0,05)$ dan terjadi interaksi yang nyata $(p<0,05)$ antara perlakuan suplementasi ekstrak cengkeh $2 \%$ dengan waktu fermentasi. Selama proses fermentasi terjadi peningkatan total probiotik pada Bifidus milk probiotik baik dengan suplementasi ekstrak cengkeh $2 \%$ maupun
Tabel 1. Total Bifidobacterium bifidum (log CFU/mL) dalam Bifidus milk dengan suplementasi ekstrak cengkeh

\begin{tabular}{lccc}
\hline \multirow{2}{*}{ Bifidus milk } & \multicolumn{2}{c}{ Waktu fermentasi } & \multirow{2}{*}{ Rerata } \\
\cline { 2 - 3 } & Sebelum & Sesudah & \\
\hline BM0 & $6,10 \pm 0,21$ & $9,01 \pm 0,19$ & $7,56 \pm 0,20^{\text {a }}$ \\
BM2 & $6,09 \pm 0,20$ & $9,85 \pm 0,30$ & $7,97 \pm 0,25^{\text {b }}$ \\
Rerata & $6,10 \pm 0,21^{\text {a }}$ & $9,43 \pm 0,25^{\mathrm{b}}$ & \\
\hline
\end{tabular}

a, b Superskrip yang berbeda pada baris dan kolom yang sama menunjukkan perbedaan yang nyata $(p<0,05)$

tanpa suplementasi ekstrak cengkeh. Suplementasi ekstrak cengkeh pada pembuatan Bifidus milk mampu meningkatkan total probiotik lebih tinggi $(p<0,05)$ dibandingkan dengan yogurt tanpa suplementasi ekstrak cengkeh dalam waktu inkubasi yang sama.

Rerata total probiotik pada BM0 dan BM2 berturutturut adalah 9,01 dan 9,85 log CFU/mL. Peningkatan populasi probiotik selama proses fermentasi $6,10 \mathrm{log}$ $\mathrm{CFU} / \mathrm{mL}$ pada awal fermentasi menjadi 9,43 log CFU/ $\mathrm{mL}$ pada akhir fermentasi dapat dipengaruhi oleh adanya ketersediaan nutrien didalam media yang terdiri atas susu skim bubuk dan susu segar. Pemakaian susu skim bubuk sebagai campuran dalam bahan pembuatan Bifidus milk ini memberikan suplai nutrien yaitu protein dan laktosa yang akan digunakan sebagai substrat selama proses fermentasi. Hasil penelitian ini didukung oleh penelitian yang dilakukan Marshall dan Arbuckle (1996) bahwa susu skim bubuk mengandung protein sebanyak $37 \%$, laktosa $55 \%$ dan mineral $8 \%$, sedangkan berdasarkan hasil pengujian awal (Tabel 7) sebagai bahan pembuatan Bifidus milk susu segar yang digunakan mengandung protein sebanyak 2,79\%, laktosa $4,87 \%$ dan total solid $12,31 \%$. Menurut Hutkins (2001) cit. Chandan dkk. (2006), bakteri memanfaatka laktosa sebagai sumber energi dan karbon, sedangkan kasein digunakan sebagai sumber nitrogen untuk mendukung pertumbuhannya.

Proses fermentasi menyebabkan peningkatan total probiotik secara nyata $(p<0,05)$ dari $6,10 \log \mathrm{CFU} / \mathrm{mL}$ sebelum fermentasi menjadi 9,43 log CFU/mL sesudah fermentasi. Hasil penelitian ini, baik dari BM0 maupun BM2 memenuhi standar produk Bifidus milk sebagai pangan fungsional. Sejalan dengan penelitian yang dilakukan Kailasapathy dkk. (2000) dan Homayouni dkk. (2008) bahwa untuk dapat berperan sebagai makanan fungsional maka jumlah minimum sel hidup probiotik adalah $10^{7} \mathrm{sel} / \mathrm{mL}$ atau 7 log CFU/mL produk. Penelitian yang dilakukan Tannock pada tahun 1999 menyatakan produk probiotik harus mengandung 
mikrobia viable sebesar $10^{6}-10^{8} \mathrm{CFU} / \mathrm{mL}$. Berdasarkan hasil tersebut, Bifidus milk yang diformulasikan pada studi ini telah memenuhi persyaratan sebagai salah satu produk makanan fungsional yang memiliki potensi dalam meningkatkan kesehatan.

\section{Total Bakteri}

Hasil pengujian total bakteri produk BM0 dan BM2 ditunjukkan pada Tabel 2. Perhitungan total bakteri pada produk ini dilakukan untuk mengetahui jumlah bakteri pada sampel.

Tabel 2. Total bakteri (log CFU/mL)

\begin{tabular}{cccc}
\hline \multirow{2}{*}{ Bifidus milk } & \multicolumn{2}{c}{ Waktu fermentasi } & \multirow{2}{*}{ Rerata } \\
\cline { 2 - 3 } & Sebelum & Sesudah & \\
\hline BM0 & $5,12 \pm 0,34$ & $3,50 \pm 0,20$ & $4,31 \pm 0,27^{\text {a }}$ \\
BM2 & $5,09 \pm 0,21$ & $2,05 \pm 0,19$ & $3,57 \pm 0,20^{\text {b }}$ \\
Rerata & $5,11 \pm 0,28^{a}$ & $2,78 \pm 0,20^{\text {b }}$ & \\
\hline
\end{tabular}

a, b Superskrip yang berbeda pada baris dan kolom yang sama menunjukkan perbedaan yang nyata $(p<0,05)$

Berdasarkan Tabel 2., terdapat interaksi yang nyata $(p<0,05)$ antara total bakteri sebelum dan sesudah fermentasi baik pada produk BM0 dan BM2. Total bakteri pada akhir fermentasi jauh lebih rendah daripada total bakteri sebelum fermentasi baik pada kedua produk Bifidus milk yaitu BM0 dan BM2. Suplementasi ekstrak cengkeh pada produk BM2 memberikan jumlah total bakteri yang lebih rendah dibandingkan total bakteri pada produk BM0 yaitu sebesar 2,05 log CFU/mL pada akhir fermentasi. Sehingga terdapat perbedaan yang nyata terhadap adanya suplementasi ekstrak cengkeh pada Bifidus milk.

Persentase penurunan total bakteri dari sebelum dan sesudah fermentasi pada kedua produk Bifidus milk menunjukkan hasil yang bervariasi. Pada produk BM0 menunjukkan bahwa persentase penurunan total bakteri pada produk BM0 sebesar 31,64\% dari 5,12 menjadi 3,50 log CFU/mL sedangkan pada produk BM2 sebesar 59,14\% dari 5,09 menjadi 2,05 log CFU/mL pada akhir fermentasi.

Hasil tersebut berkorelasi positif dengan viabilitas probiotik Bifidobacterium bifidum pada produk BM2 pada akhir fermentasi sebesar 9,85 log CFU/mL. Banyaknya jumlah sel probiotik yang hidup tersebut selama proses fermentasi dan sesudah fermentasi memungkinkan bakteri probiotik Bifidobacterium bifidum untuk beraktivitas melawan bakteri patogen. Hal ini juga sejalan dan didukung dari hasil pengujian antibakteri
(Tabel 3) bahwa aktivitas antibakteri tertinggi di miliki oleh produk BM2 terhadap daya penghambatan pada Staphylococcus aureus dan Salmonella typhimurium.

Sinergi antara aktivitas probiotik Bifidobacterium bifidum dan suplementasi ekstrak cengkeh pada produk BM2 mampu memberikan nilai lebih produk tersebut terhadap penurunan total bakteri pada susu fermentasi yang berimplikasi pada kesehatan. Beberapa penelitian telah banyak mengkaji mengenai manfaat cengkeh, diantaranya studi yang dilakukan Razafimamonjison dkk. (2015) menyampaikan bahwa eugenol merupakan senyawa utama (72-90\%) pada cengkeh yang menyebabkan cengkeh memiliki aroma yang khas. Selain itu, senyawa ini bersifat antiseptik dan anestetik. Bhuiyan dkk. (2010) juga melakukan kajian terkait penggunaan GC-MS untuk menganalisis senyawa daun cengkeh asal Bangladesh. Berdasarkan hasil analisis tersebut senyawa terbanyak yang muncul adalah eugenol $(74,28 \%)$ kemudian eucalyptol $(5,78 \%)$, kariofilen $(3,85 \%)$ diikuti dengan a-cardinol $(2,43 \%)$ dan limonen $(2,08 \%)$.

Nurhidayati dan Sulistiowati (2013) menambahkan bahwa kandungan minyak atsiri pada cengkeh memiliki potensi tinggi bagi kesehatan, diantaranya sebagai anestetik, antimikrobial, antiseptik dan antioksidan. Dehgani dkk. (2012) juga menambahkan bahwa minyak atsiri pada cengkeh juga dapat berperan sebagai imunomodulator. Hal ini juga sejalan dengan penelitian yang dilakukan oleh Dibazar dkk. (2014) bahwa daun cengkeh bermanfaat dalam menangkal radikal bebas karena adanya komponen fenolik seperti antioksidan dan falavonoid.

Widiyaningsih (2018) juga menyampaikan terkait peranan probiotik Bifidobacterium bifidum. Bifidobacterium bifidum merupakan mikroflora alami saluran pencernaan sehingga bayak terdapat pada usus dan saluran reproduksi seperti mukosa vagina. Bifidobacterium bifidum memiliki peran sebagai probiotik yang dapat menghambat pertumbuhan bakteri patogen seperti E. coli, Salmonella, dan Clostridium. Mekanisme pencegahan pertumbuhan pathogen ini disebabkan oleh adanya produksi asam laktat dan asam asetat yang dapat menurunkan pH lingkungan usus, sehingga akan berdampak terhadap pertumbuhan pathogen. Studi in vivo pada penelitian yang dilakukan Widiyaningsih (2018), menunjukkan adanya konsumsi Bifidobacterium bifidum dan Bifidobacterium breve melalui oral, mampu menghambat aktivitas toksin cholera yang disuntikkan pada tikus uji. Parameter ini diperoleh dengan mengukur ovalbumin dan immunoglobulin A. Hasil pengukuran tersebut memberikan gambaran bahwa terjadi peningkatkan ovalbumin dan Imunoglobulin A untuk menghambat aktivitas toksin cholera pada tikus. 


\section{Aktivitas Antibakteri Susu Bifidus (Bifídus Milk)}

Pengukuran aktivitas antibakteri dalam Bifidus milk dilakukan untuk mengetahui pengaruh suplementasi ekstrak cengkeh dalam produk susu tersebut terhadap pertumbuhan patogen uji. Aktivitas antibakteri dilakukan dengan mengukur zona bening yang dihasilkan selama pengujian terhadap bakteri patogen (Tabel 3 ).

Tabel 3. Luasan zona bening Bifidus milk (mm) terhadap pertumbuhan pathogen uji

\begin{tabular}{ccr}
\hline \multirow{2}{*}{ Bifidus milk } & \multicolumn{2}{c}{ Bakteri patogen } \\
\cline { 2 - 3 } & $\begin{array}{c}\text { Staphylococcus } \\
\text { aureus }\end{array}$ & $\begin{array}{c}\text { Salmonella } \\
\text { typhimurium }\end{array}$ \\
\hline BM0 & $7,22 \pm 0,05$ & $8,15 \pm 0,21$ \\
BM2 & $11,35 \pm 0,10$ & $14,18 \pm 0,15$ \\
\hline
\end{tabular}

Berdasarkan hasil pengujian, menunjukkan bahwa baik kombinasi antara suplementasi ekstrak cengkeh $2 \%$ dengan probiotik Bifidobacterium bifidum pada BM2 maupun pada produk fermentasi BM0 samasama berpotensi melawan aktivitas patogen. Akan tetapi, luasan zona bening tertinggi yang merupakan perwujudan dari aktivitas antibakteri ditunjukkan pada aktivitas antibakteri pada produk BM2.

Kemampuan antibakteri dilihat berdasarkan luasan zona bening, jika zona bening yang terbentuk $>2 \mathrm{~mm}$, menunjukkan bahwa positif memiliki daya hambat terhadap bakteri patogen. Pada Tabel 3, dapat dilihat bahwa baik pada BM0 maupun BM2 untuk kedua bakteri yaitu Staphylococcus aureus dan Salmonella typhimurium olahan susu Bifidus menunjukkan daya hambat positif $>2 \mathrm{~mm}$. Selanjutnya, jika diperhatikan lebih seksama daya hambat tertinggi yaitu pada produk susu BM2 terhadap Salmonella typhimurium dengan daya hambat $14,18 \mathrm{~mm}$, sedangkan untuk Staphylococcus aureus FNCC 0047 daya hambat sebesar 11,35 mm.

Besaran zona bening pada Tabel 3 juga menunjukkan, baik pada produk BM0 dan BM2, keduanya memiliki zona penghambatan yang lebih tinggi pada Salmonella typhimurium jika dibandingkan zona penghambatan pada Staphylococcus aureus. Dengan demikian, hasil penelitian tersebut menunjukkan bahwa produk susu fermentasi memilki penghambatan yang kuat terhadap pertumbuhan Salmonella typhimurium. Hasil penelitian inijuga didukung oleh beberapa penelitian terkait antibakteri susu fermentasi diantaranya hasil penelitian Kaboosi (2011) yang menunjukkan bahwa yoghurt komersial yang mengandung Lactobacillus $s p$., Streptococcus sp. dan Bifidobacterium sp mampu menghambat pertumbuhan Salmonella typhii secara bakteriostatik dan bakteriosida. Studi antibakteri oleh susu Bifidus ini juga sejalan dengan penelitian yang dilakukan oleh Yesillik dkk. (2011) bahwa Salmonella typhimurium memiliki sensitifitas tinggi terdap produk susu fermentasi seperti yoghurt murni (homemade dan komersial), kefir komersial dan yoghurt probiotik.

Hasil penelitian lain juga ditunjukkan oleh Poeloengan (2012) bahwa yoghurt probiotik memiliki kecenderungan penghambatan yang baik terhadap pertumbuhan bakteri gram Negatif (Salmonella thypii dan Escherichia coli) dibandingkan pertumbuhan bakteri gram Positif (Staphylococcus. aureus dan Bacillus cereus). Penelitian lain juga berpendapat bahwa mekanisme tersebut disebabkan karena keberadaan dari komponen senyawa antibakteri,yaitu asam-asam organik (Branen and Davidson, 1993). Produk metabolisme kelompok BAL yaitu asam laktat dan asam asetat memiliki aktivitas tinggi sebagai antimikroba (Suskovic dkk., 2010) yang memiliki spektrum penghambatan luas (Rahayu dkk., 2013).

Berdasarkan luasan zona bening, spektrum daya hambat dapat diklasifikasikan. Daya hambat bakteri merupakan kemampuan suatu senyawa dalam melakukan penghambatan menghambat pertumbuhan bakteri. Pertumbuhan bakteri berdasarkan kategori respon zona hambat menurut klasifikasi Davis and Stout (1971) ditampilkan dalam Tabel 4.

Tabel 4. Klasifikasi spektrum daya hambat

\begin{tabular}{cc}
\hline Diameter zona & Respon hambatan \\
\hline $0 \mathrm{~mm}$ & Tidak ada \\
$5-10 \mathrm{~mm}$ & Lemah \\
$11-20 \mathrm{~mm}$ & Kuat \\
$>22 \mathrm{~mm}$ & Sangat kuat \\
\hline
\end{tabular}

Berdasarkan tersebut, maka dapat dilakukan pengklasifikasian yaitu produk BMO memiliki respon penghambatan yang lemah pada Staphylococcus aureus FNCC $0047(7,22 \mathrm{~mm})$ dan Salmonella typhimurium $(8,15 \mathrm{~mm})$, sedangkan pada produk BM2 respon penghambatan tergolong kuat baik pada Staphylococcus aureus FNCC 0047 maupun Salmonella typhimurium. Hal ini terjadi karena adanya aktivitas probiotik Bifidobacterium bifidum yang berperan dalam melawan patogen bersinergi dengan kandungan bahan kimia cengkeh yang bersifat antibakteri seperti minyak atsiri yaitu eugenol. Hasil penelitian ini sesuai dengan pernyataan Martinez dkk. (2013), bahwa terjadi aktivitas penghambatan terhadap pertumbuhan bakteri Staphylococcus aureus, Esherichia coli, Bacillus cereus dan Salmonella typhii oleh bakteriosin asal Bifidobacterium lactis dan Bifidobacterium longum 
mampu menghambat. Penelitian yang dilakukan Alakomi dkk. (2006) menunjukkan tingkat sensitifitas bakteri pathogen uji berbanding lurus dengan luasan zona bening. Mekanisme penghambatan terjadi karena produk utama metabolisme BAL yaitu asam laktat dapat menurunkan permebilitas membrane sel sehingga tidak stabil dan merusak membran luar bakteri Gram negatif.

Penghambatan pertumbuhan beberapa bakteri Gram negatif dan Gram positif terjadi karena peran dari bakteriosin Bifidobacterium. Struktur dinding sel bakteri uji merupakan salah satu faktor yang mempengaruhi daya kerja bakteriosin tersebut (Martinez dkk., 2013). Penelitian yang dilakukan oleh Perez dkk. (2014) memberikan penjelasan bahwa mekanisme kerja pertama bakteriosin terhadap penghambatan pertumbuhan bakteri melalui perusakan permeabilitas membran sel dimulai dengan membentuk pori sehingga menyebabkan terjadinya kebocoran pada membran sel. Sari dkk. (2012) menjelaskan lebih lanjut bahwa adanya kebocoran pada membrane sel mengakibatkan ketidakstabilan membran sel sehigga pertumbuhan terhambat dan sel mengalami kematian.

Hal ini didukung dengan pendapat Nazzaro dkk. (2013) yang menyatakan bahwa aktivitas antibakteri minyak atsiri dari bunga cengkeh mampu menghambat pertumbuhan pathogen dibuktikan dengan terbentuknya zona bening. Komponen dan persentase senyawa penyusun pada minyak atsiri berpengaruh terhadap kekuatan aktivitas antibakteri. Xing dkk. (2012) juga menambahkan bahwa eugenol (70-96\%) merupakan komponen utama minyak atsiri ekstrak bunga cengkeh dan termasuk dalam golongan fenol yang efek toksisitas. Efek toksik ini terjadi jika eugenol berinteraksi dengan enzim dan protein pada membrane dengan menembus membrane sel maka akan terjadi aliran proton berlawanan yang dapat merusak aktivitas sel bakteri target.

Devi dkk. (2010) juga menyampaikan terkait mekanisme eugenol sebagai antibakteri. Mekanisme tersebut terjadi melalui 2 cara penghambatan yaitu dengan menembus bagian membran sitoplasma dan mengganggu permeabilitas dinding sel bakteri. Mekanismme tersebut didukung dengan sifat fisiko kimia eugenol yang hydropobic (tidak larut dalam air) sehingga menyebabkan eugenol berinteraksi dengan lipopolisakarida pada membran sel bakteri khususnya bakteri Gram negatif dan struktur dinding sel mengalami perubahan. Perubahan struktur dinding sel tersebut menyebabkan kebocoran pada bagian intrasel.

Ristiansyah dkk. (2018) menambahkan jika ekstrak daun cengkeh dengan varian konsentrasi mulai dari $10,15,20$, dan $25 \%$ terbukti memiliki efek antibiotik terhadap pertumbuhan bakteri Salmonella typhi. Daya hambat dengan respon penghambatan yang kuat ditunjukkan pada ekstrak daun cengkeh $25 \%$ dengan daya hambat $16,90 \mathrm{~mm}$. Tingginya konsentrasi ekstrak daun cengkeh sebanding dengan luasan zona hambat yang didapatkan dengan zona hambat pertumbuhan bakteri rata-rata tertinggi terdapat pada konsentrasi.

Daya hambat ekstrak cengkeh tidak hanya pada Staphylococcus aureus FNCC 0047 dan Salmonella typhimurium, akan tetapi juga pada bakteri patogen lainnya. Kajian aktivitas antibakteri pada ekstrak bunga cengkeh juga dilaporkan oleh Pailing dkk. (2016). Hasil peneitian tersebut menunjukkan bahwa ekstrak bunga cengkeh mampu menghambat pertumbuhan Porphyromonas gingivalis ditandai dengan munculnya zona bening $(13,01 \mathrm{~mm})$. Porphyromonas gingivalis ini merupakan kelompok bakteri Gram negatif, bersifat anaerob dan merupakan mikroflora alami rongga mulut. Tingginya populasi bakteri ini dapat menyebabkan penyakit periodontitis.

\section{KESIMPULAN}

Suplementasi ekstrak cengkeh sebesar 2\% sebagai bahan suplementasi pada Bifidus milk dapat meningkatkan viabilitas probiotik Bifidobacterium bifidum sebesar 24\%. Ekstrak cengkeh dalam produk Bifidus milk juga berperan sebagai agen preservatif yang didukung dengan adanya aktivitas antibakteri terhadap Staphylococcus aureus dan Salmonella typhimurium dan penurunan total bakteri pada Bifidus milk sebesar $43 \%$.

\section{UCAPAN TERIMA KASIH}

Ucapan terima kasih penulis sampaikan kepada Universitas 'Aisyiyah Yogyakarta melalui LPPM, atas bantuan dana yang diberikan melalui skema Hibah Internal dengan Surat Tugas Pelaksanaan Penelitian Nomor 05/LPPM/UNISA/XI/2017， Tanggal 09 November 2017.

\section{KONFLIK KEPENTINGAN}

Dengan ini kami menyatakan bahwa tidak terdapat konflik kepentingan dalam artikel ilmiah yang kami tulis.

\section{DAFTAR PUSTAKA}

Adriani, L. (2010). Yoghurtsebagai Probiotik, dalam Soeharsono (eds). Probiotik. Bandung: Widya Padjadjaran.

Alakomi, H. L., Paanaen, A., Suihko, M. L., \& Saarela, H. M. (2006). Weaking effect of cell permeabilizer on gram 
negative bacteria causing biodeterioration. Journal of Applied Environmental Microbiology, 72(7), 695-4703. https://journals.asm.org/doi/10.1128/AEM.00142-06

Ambarwati Y. K. 2004. Pengaruh penambahan madu dan lama penyimpanan terhadap total bakteri dan daya terima susu pasteurisasi. Skripsi. Universitas Diponegoro. Semarang.

Banerjee, G. C. (2008). A Text Book of Animal Husbandry. $8^{\text {th }}$ ed. p: 933. Oxford and IBM Publishing Co. Pvt. Ltd. New Delhi: India

Branen, A. L., dan Davidson, P. M. (1993). Antimicrobial in Foods. $2^{\text {nd }}$ ed. New York: Marcel Dekker, Inc.

Bhuiyan, Md., N. I., Bagum, J., Nandi, N. C., \& Akter, F. (2010). Constituents of the essential oil from leaves and buds of clove (Syzigium aromaticum). African Journal of Plant Science, 4(11), 451-454. https://doi.org/10.5897/ AJPS. 9000051

Chandan, R. C., White, C. H., Kilara, C., \& Hui, Y. H. (2006). Manufacturing Yogurt and Fermented Milks Handbook. Blackwell Publishing Ltd. USA.

Dehghani, F., Heshmatpour, A., Panjehshahin, M. R., \& Khozani, T. T. (2012). Toxic effects of water/ alcoholic extract of Syzygium aromaticum on sperm quality, sex hormones and reproductive tissues in male mouse. IUFS Journal of Biology, 71(2), 95 - 102. https://www. researchgate.net/publication/259389530

Dibazar, S. P., Fateh, S., \& Daneshmandi, S. (2014). Clove (Syzigium aromaticum) ingredients affect lymphocyte subtypes expansion and cytokine profile responses: an in vitro evaluation. Food and Drug Analysis, 22(4), 448454. https://doi.org/10.1016/j.jfda.2014.04.005

Dave, R. I., \& Shah, N. P. (1997). Viability of yogurt and probiotics bacteria in yogurts made from commercial stater cultures. International Dairy Journal, 7(1): 31-41, https://doi.org/10.1016/S0958-6946(96)00046-5

Davis, W. W., \& Stout, T. R. (1971). Disc plate method of microbiological antibiotic assay. Applied Microbiology, 22(4), 659-665. https://www.ncbi.nlm.nih.gov/pmc/ articles/PMC376382/

Devi, K. P., Nisha, S. A., Sakthivel, R., \& Pandian, S. K. (2010). Eugenol (an essential oil of clove) acts as an antibacterial agent against Salmonella typhi by disrupting the cellular membrane. Journal of Ethnopharmacology, 130(1), 107115. https://doi.org/10.1016/j.jep.2010.04.025

Gustaw W., Kordowska, W. M., \& J. Koziol. (2011). The influence of selected prebiotics on the growth of lactic acid bacteria for bio-yoghurt production. Acta Scientiarum Technologia Alimentaria, 10(4), 455-466. https://pubmed.ncbi.nlm.nih.gov/22230927/

Haenlein, G. F. W. (2004). Goat milk in human nutrition. Small Ruminant Research, 51(2): 155-163. https://doi. org/10.1016/j.smallrumres.2003.08.010
Hakim, L. (2015). Rempah dan Herba: Kebun Pekarangan Rumah Masyarakat. Yogyakarta: Dandra, Pustaka Indonesia.

Homayouni, A., Ehsani, M. R., Azizi, A., Razavi, S. H., \& Yarmand, M. S. (2008). Growth and survival of some probiotik strains in simulated ice cream conditions. Jurnal of Applied Science, 8(2), 379-382. https://scialert.net/ abstract/?doi=jas.2008.379.382

Irianto, K. (2013). Mikrobiologi Medis. Bandung: Alfabeta.

Jacobsen, C. N., Nielsen, V. R., Hayford, A. E., Moller, P. L., Michaelsen, K. F., Pærregaard, A., Sandstrom, B., Tvede, M., \& Jakobsen, M. (1999). Screening of Probiotic Activities of Forty-Seven Strains of Lactobacillus spp. by In Vitro Techniques and Evaluation of the Colonization Ability of Five Selected Strains in Humans. Applied and Environmental Microbiology, 65(11), 4949-4956. https://journals.asm.org/doi/10.1128/AEM.65.11.49494956.1999; DOI: 10.1128/AEM.65.11.4949-4956.1999.

Kailasapathy, K., Sultana, K., \& Godward, G. (2000). Probiotic bacteria: Improved delivery by bioencapsulation. Probiotica 9, 2-7.

Kaboosi, H. (2011). Antibacterial effects of probiotics isolated from yoghurts against some common bacterial pathogens. African Journal of Microbiology Research, 5(25), 4363-4367. DOI: 10.5897/AJMR11.474

Kumala, S., Yuliani, D., \& Tulus. 2009. Pengaruh pemberian rebusan kayu secang(Caesalpinia sappan L.) terhadap mencit yang diinfeksi bakteri Escherichia coli. Jurnal Farmasi Indonesia, 4(4), 188 -198.

Kumala, S., Devana, D., \& Tulus. (2013). Aktivitas antibakteri rebusan secang (caesalpinia sappan I.) terhadapSalmonella thypii secara in vivo. agriTECH, 33(1), 54-71. https://dx.doi.org/10.22146/agritech.9566

Laitupa, F., \& Susane, L. (2010). Pemanfaatan eugenol dari minyak cengkeh untuk mengatasi ranciditas pada minyak kelapa. Jurusan Teknik Kimia, Fakultas Teknik, Universitas Diponegoro. http://kimia.undip.ac.id (1 April 2018).

Lankaputhra, W. E. V., \& Shah, N. P. (1997). Improving viability of Lactobacilus acidophilus and Bifidobacteria in yogurt using two step fermentation and neutralised mix. Food Australia, 49(8), 363-366. http://pascal-francis.inist.fr/ vibad/index. php?action $=$ getRecordDetail\&idt $=2781775$

Laroia,, S., \& Martin, J. H. (1991). Methods for enumerating and propagating bifidobacteria. Cultured Dairy Products Journal, 26, 32-33.

Maitimu, C. V., Legowo, A. M., \& Al-Baarri, A. N. (2013). Karakteristik Mikrobiologis, Kimia, Fisik, dan Organoleptik Susu Pasteurisasi dengan Penambahan Ekstrak Daun Aileru (Wrightia calycina) Selama Penyimpanan. Jurnal Aplikasi Teknologi Pangan, 2(1), 18-29. http://www. jatp.ift.or.id/index.php/jatp/article/view/96/63 
Marshall, R.T., \& Arbuckle, W.S. (1996). Ice cream. $5^{\text {th }}$ ed. Chapman and Hall, New York.

Martinez, F. A. C., Eduardo, Attilio, M. B., Paul, C. D., \& Ricardo, P. S. O. (2013). Bacteriocin Production by Bifidobacterium Spp. A Review. Biotechnology Advances, 31(4), 482-488. https://doi.org/10.1016/j. biotechadv.2013.01.010

Miksusanti., Fitrya, N., \& Marfinda. (2011). Aktivitas campuran ekstrak kulit manggis (Garcinia mangostana L.) secang (Caesalpina sappan L.) terhadap Bacillus cereus. Jurnal Penelitian Sains. 14 (3), 141-147. https://doi. org/10.26554/jps.v14i3.214

Nazzaro, F., Fratianni, F., Martino, L. D., Coppol, R., \& Feo, V. D. (2013). Effect of essential oils on pathogenic bacteria. Pharmaceuticals. 6, 1451-1474. https://www.mdpi. com/1424-8247/6/12/1451. https://doi.org/10.3390/ ph6121451

Nurhidayati, L., \& Sulistiowati. (2013). Penetapan kadar eugenol dalam minyak atsiri dari tiga varietas bunga cengkeh (Syzygium aromaticum(L) Merr. \& L.M. Perry) secara kromatografi gas. Seminar Nasional dalam Rangka Lustrum X Fakultas Farmasi Univesitas Pancasila.

Pailing, A., Posangi, J., \& Anindita, P.S. (2016). Uji daya hambat ekstrak bunga cengkeh (Syzygium aromaticum) terhadap bakteri Porphyromonas gingivalis. Jurnal e-GiGi (eG), 4(2), 229-234. https://doi.org/10.35790/ eg.4.2.2016.14159

Park, W. Y. (2009). Bioactive Component in Milk and Dairy Products. CRC Press, USA

Perez, R. H., Zendo, T., dan Sonomoto, K. (2014). Novel bacteriocins from lactic acid bacteria (LAB): various structures and applications. Microbial Cell Factories, 13(1), 1-13. https://microbialcellfactories. biomedcentral.com/articles/10.1186/1475-2859-13S1-S3, DOI: $10.1186 / 1475-2859-13-S 1-S 3$

Poeloengan, M. (2012). Pengujian Yoghurt Probiotik pada Pertumbuhan Bakteri. Prosiding Semiloka Nasional Prospek Industri Sapi Perah Menuju Perdagangan Bebas 2020, Bogor, 303-307.

Rahayu, E. S., Yogeswara, A., Haryono, M. P., Utami, I. S., Utami, T., Nurfiani, S., \& Cahyanto, M.N. (2013). Bakteri Asam Laktat Indigenous Berpotensi Probiotik dan Aplikasinya untuk Produksi Susu Fermentasi. Prosiding Seminar Intensif Riset Sinas, Jakarta, 149-159.

Razafimamonjison G., Jahiel, M., Duclos, T., Ramanoelina, P., Fawbush, F., \& Danthu, P. (2014). Bud, leaf and stem essential oil composition of Syzigium aromaticum from Madagascar, Indonesia and Zanzibar. International Journal of Basic and Applied Sciences, 3(3), 224-233. http://www.sciencepubco.com/index.php/ijbas/article/ view/2473
Ristiansyah, D. U., Yenita., Melviana, dan Annisa. (2018). Uji Efektivitas Antibiotik Ekstrak daun cengkeh (Syzgium aromaticum) terhadap pertumbuhan bakteri Salmonella typhi secara in vitro. Jurnal Ibnu Sina Biomedika, 2(1): 41-47. http://jurnal.umsu. ac.id/index.php/biomedika/article/view/1901, http:// dx.doi.org/10.30596\%2Fisb.v2i1.1901

Sari, R. A., Nofiani, R., \& Ardiningsih, P. (2012). Karakterisasi Bakteri Asam Laktat Genus Leuconostoc dari Pekasam Ale-Ale Hasil Formulasi Skala Laboratorium. Jurnal Kimia Khatulistiwa, 1(1), 14-20. https://jurnal.untan.ac.id/ index.php/jkkmipa/article/view/992/941

Suskovic, J., Kos, B., Beganovic, J., Pavunc, A.L., Habjanic, K., \& Matosic, S. (2010). Antimicrobial Activity-The Most Important Property of Probiotic and Stater Lactic Acid Bacteria. Food Technology and Biotechnology, 48(3), 296-307. https://hrcak.srce.hr/57561

Taofik, A., \& Depison. (2008). Hubungan antara lingkar perut dan volume ambing dengan kemampuan produksi susu kambing Peranakan Etawah. Jurnal IImiah IImu-ilmu Peternakan, 11(2), 59 - 65. https:// online-journal.unja.ac.id/jiip/article/view/749. https:// doi.org/10.22437/jiiip.v11i2.749

Tannock, G. W. (1999). Probiotic: A Critical Review. Horizon Scientific Press, England.

Vinderola, C. G., \& Reinheimer, J. A. (1999). Culture media for the enumeration of Bifidobacterium bifidum and Lactobacillus acidophilus in the presence of yoghurt bacteria. International Dairy Journal, 9(8), 497-505. https://doi.org/10.1016/S0958-6946(99)00120-X

Wahyu, S. S., Julaikha, S., Suranto., Susanti, S., Lorentina, Y., Sopian, Y., \& Arfah, Z. F. (2012). Pengujian Total Bakteri/Total Plate Count (TPC). Departemen Pendidikan Nasional. Jakarta.

Waluyo, L. (2008). Metode Teknik Dasar Mikrobiologi. Universitas Muhammadiyah Malang. Malang.

Widiyaningsih, E. N. (2011). Peran Probiotik Untuk Kesehatan. Jurnal Kesehatan, 4(1), 14-20

Widodo. (2003). Bioteknologi Industri Susu. Lacticia Press, Yogyakarta.

Winarti, C., \& Sembiring B. S. (1998). Pengaruh cara dan lama ekstraksi terhadap kadar tanin ekstrak kayu secang (Caesalpinia sappan L). Balitro Bogor. Warta Tumbuhan Obat Indonesia, 4(3), 17-18. http:// ejournal.litbang.kemkes.go.id/index.php/wtoi/article/ view/2722

Xing, Y., Xu, Q., Li, X., Che, Z., \& Yun, J. (2012). Antifungal activities of clove oil against Rhizopus nigricans, Aspergillus flavus and Penicillium citrinum in vitro and in wounded fruit test. Journal Food Safety, 32(1), 84-93. https://doi.org/10.1111/j.1745-4565.2011.00347.x 
Yesillik, S., Yildirim, N., Dikici, A., Yildiz., \& Yesillik, S. (2011). Antibacterial Effects of Some Fermented Commercial and Homemade Dairy Products and 0.9\% Lactic Acid Against Selected Foodborne Pathogens. Asian Journal of Animal and Veterinary Advances, 6(2): 189-195. https://scialert.net/abstract/?doi=ajava.2011.189.195, DOI: 10.3923/ajava.2011.189.195 